\title{
The Terms of Address of Abung Lampungese Language as a Local Wisdom in Its Multicultural Society
}

\author{
Iing Sunarti \\ Universitas Lampung, Bandar Lampung, Indonesia \\ Sumarti \\ Universitas Lampung, Bandar Lampung, Indonesia \\ Bambang Riadi \\ Universitas Lampung, Bandar Lampung, Indonesia
}

\begin{abstract}
As a multiethnic and multilingual population, Lampung province can be broadly divided into two groups; the indigenous population (Lampung ethnic) and immigrant population. Abung Lampungese community, as one of Lampung ethnic, has a unique and varied terms of address, and it also has a rule of use. This study aims to investigate the forms and the rules of terms of address used in Abung Lampungese by using qualitative descriptive design, observation and interview as the data collection techniques. There are ten terms of address and twelve factors of the terms of address rules and norms in Lampungese found in this study, each of which portrays the relationship between the speaker and the interlocutor.
\end{abstract}

Index Terms - terms of address, kinds of terms of address, norms in using the terms of address

\section{INTRODUCTION}

Language and cultures are related to each other; 1) language expresses cultural reality, 2) language embodies cultural realities, 2) language embodies cultural reality, 3) language symbolizes cultural reality. Those relations are the must preserved trasures of local wisdoms in Lampungese society. The ethnic of Lampungese society has an ethic or a norm which becomes the guideline in managing behavior when they communicate and interact between ethnic groups and other ethnic groups, both are those who have family relations, and those who are not relatives

As a multiethnics and multilingual province, Lampung is inhabitated by various ethnics broadly divided into two groups; indigeneous population (Lampungese ethnic) and immigrant population. Based on their customs, the people of Lampung are distinguished into Saibatin and Pepadun people. Saibatin people live in coastal area, while Pepadun people live alongside the river empties into the Java Sea in the rural areas. Therefore, the symbol of Lampung Province is known as Sang Bumi Ruwa Jurai which means the noble residence of two different origin and different customs group of people.

Both Saibatin and Pepadun have the same character traits as their life philosophy known as Pi-il Pesenggiri. Abung Lampungese people as one of Pepadun ethnics also has Pi-il Pesenggiri as their life philosophy. This Pi-il Pesenggiri reflects the characters of Abung Lampungese society in these features (1) Pi-il Pesenggiri (pride). This Pi-il Pesenggiri is seen in their behavior, they feel they have pride. Every Lampungese acts as if he is a great person, and each relative is greater than other relatives. (2) Juluk Adek (having title). In this pi-il, they show their desire to be respected. Though they are still young, they use nama besar (great name) called Juluk/jejuluk to fulfil their desire. After getting married, they will use nama tua (old name) or courtesy title called adok/adek. (3) Nemui Nyimah (open arms). They love getting praise, this is a part of their pi-il. They love having guests, giving things and sending gifts to certain people, especially to those bounded in kinship, to get praises. Besides, this pi-il reflects that Lampungese People easily forgive others' mistakes. (4) Nengah Nyapur (socialization). Lampungese people love visiting, making new friends, having chit chat and discussion. (5) Sakai Sambayan (help each other). Lampungese people love helping each other. They also love helping others in preparing and finishing a heavy work, such as building a house, opening forest, and holding a custom party. (Hadikusuma: 1988).

Related to those five pi-il above, the terms of address are closely related to Pi-il Juluk Adek (titled name). In this pi-il, it is crystal clear that Lampungese ethnic love giving courtesy title which used as a term of address. Since the first day of birth, children are already given courtesy titles called Juluk/Jejuluk such as Darmawan, Bangsa Ratu, Abdullah, Sitti, Permai. Juluk is used as long as this person is single/unmarried. When the person gets married, he or she will be addressed Adek/Adok as his or her courtesy title, for example Suntan Pukuk, Pengiran Permai, Sutan Darmawan, Ratu Mahkota. 
Language is closely related to culture of speaker's social life. Kramch (1998) states that there are three connections between language and culture. First, language expresses cultural reality. The language or words expressed by the speakers refer to the experience the speaker has experienced. They express facts, ideas, or events that can be communicated, because they refer to knowledge about the world that other people also understand. In addition, Wijana, I Dewa Putu and Rohmadi (2006) also stated that words can also reflect the speaker's attitude, beliefs, and views of life.

Second, language embodies cultural reality. In addition to expressing the experience, the community members or social groups creates the experiences through language. They give meaning to create their experiences through language media, choose language media to communicate with others. As the example, when talking through phone, writing letter through e-mail, reading newspaper or interpreting a graphic or chart. The ways people communicate through talking, reading or visual media create understandable meaning, such as speaker tone, accent, conversation style, conversation style, gesture and facial expression. Soepomo (2009) also stated that verbal and nonverbal aspects show language as an incarnation of cultural reality. Third, language symbolizes cultural reality. Language is a sign system that reflects the cultural value of its people. The identity of the speakers can be seen from the language they are used. Language is a symbol of social identity of the community.

Koentjaraningrat (1990) also stated the connection of language and culture by elaborating the elements of cultural universals. The elements of cultural universals are (1) language, (2) knowledge system, (3) social organization, (4) daily equipment and technology system, (5) livelihood system, (6) religious system, and (7) art.

Sapir-Whorf postulated the theory of connection between language and culture of the societies. This theory is known as Sapir-Whorf hypothesis or Linguistic Relativity theory. This theory is quoted by Poedjosoedarmo (1968), Wardhaugh (1986), Trudgil (1995), Lyons (1995), Sibarani (2004) and Wijana and I Dewa Putu (2010). Sapir-Whorf stated that the relation between language and certain society is an integral part of its culture and the lexical distinction made by each language tend to reflect the characteristics of objects, institutions, and activities which culturally important in that society.

Abung Lampungese ethnic society has Lampungese language as the embodiment of the culture of Lampungese people. The linguistic terms used in addressing someone is called tutugh/tutur/tutor. Tutugh/tutur/tutor is a term of address, the way of addressing or addressing a member of one relative with another relative (Hadikusuma, Arifin, Barusman: 1966). Kiai, niay, apak, bati, abati, bak, ama, akan, Ayah, Apak Hou, Apak Ngah, Om, Abati, Menak, and Kholi are the examples of tutugh/tutur/tutor.

Lampungese people has mores and norms in communicating, the way of addressing someone is part of it. Younger people should lower the intonation when speaking to the elder or respected people, between in-law (sabai) both male and female should use the terms of address saya (I) and puskam (sir), between daughter in-law/son in-law (anak mattuw) and mother/father in-law (mintuha, metohou), daughter in-law/son in-law should show respect to the father/mother in law by addressing him/herself as hikam (I) and puskam (sir/madam). On the contrary, father/mother in-law address nikam, metei, kuti (You) to his/her daughter/son in-law and it is inappropriate to address niku (you) to his/her daughter/son in-law. Those who can not address his opponent's speech correctly is considered as less civilized. (Hadikusuma, Arifin, \& Barusman: 1996).

The uniqueness, roles, and norms contained in the terms of address in Abung Lampungese Language need to be studied further. As an asset of regional and national culture, it needs attention, protection and development, therefore further research and description are needed descriptively, this research informs the reader about the terms of address in Abung Lampungese Language and the rules and norms of the use of terms of address of Abung Lampungese Language.

\section{METHOD}

The researchers use observation and interview in collecting the data in this descriptive research. Observation is used when the researchers observes the utterances produced by the informant when they communicate with others. Interview is used to seeking the information related to the terms of address (the terms of address, factors considered in determining and using terms of address, and the traditional authority of giving and using the terms of address).

The data sources in this research are the spoken utterances as a primary data. These utterances are used by the native speakers of Lampungese language in their daily life communication. To determine that the spoken utterances as the sources of the data, the utterances should meet these criteria: (1) spoken utterances are actual language (parole) as individual system realization; (2) spoken utterances descriptively and empirically fulfill the language; (3) oral utterances of Lampungese language are still used as a means of communication and interaction of native speakers of Lampungese in their daily life. In collecting the data, the researchers determine some criteria of the native speakers of Lampungese; (1) the speaker is old enough and healthy (not senile) (2) the speaker is native speaker of Lampungese language; (3) the speaker has a good language ability; (4) the speaker is an indigeneous resident in the target research location. The selected informants consist of two groups; a group of traditional authority leaders and a group of ordinary community. Both groups use Lampungese language. A group of traditional authority leaders is selected based on the assumption that they have insight, know the terms of address, traditional authority in addressing someone, and rules of giving and using the terms of address in Lampungese language. Lampungese community groups are assumed as a real user of terms of address in Lampungese language in their daily communication. The total number of informants interviwed are 100 persons. 
The research was conducted in the area where the native speakers of Abung Lampungese people live, Kota Madya Bandar Lampung, Lampung Province. Bandar Lampung is the capital city of Lampung province. It is quite representative for the research since it is a miniature of Lampung. The research took place in five sub-districts; Kedaton, Rajabasa, Kemiling, Teluk Betung Selatan and Sukabumi. The researchers used participant-observation technique and questionnaire as dta collection method.

Furthermore, in data analysis technique, componential analysis was used. The data of terms of address collected were compared one to another, and the results of the comparison became the distinctive feature. This semantic distinctive features are the speech components which become the external and social factors that underlie the emergence of terms of address. Those factors also become the distinctive feature of each term of address used by the speaker. Factors are adjusted to determined factors in Lampung community culture. Those factors are gender (male/female), age (older younger, same age $(1,2,3,4$, etc.), courtesy title (customary institutions, marital status, birth order), family descent (ordinary family, religious family, noble family, or non noble family), level of formalities (intimate or regular), situation of conversation (formal atau informal), the purpose of conversation, intimate, and spiritual.

\section{RESULT AND DISCUSSION}

\section{A. The Form of Terms of Address in Abung Lampungese Language}

Based on the data of the research, the Abung Lampungese Language speakers groups are part of Lampung society who use Abung Lampungese Language. This group has unique and varied terms of address compared to others Lampungese speakers. It is classified into kinship's terms of address and non kinship's terms of address. The rules of using the terms of address are varied. They depend on gender, generation, family's environment, level of relationship, situation of conversation, the origin of title, the differences in courtesy title degree, differences of birth order, spiritual, and intimate terms of addressing someone. The following explanations are the term of address used in Abung Lampungese society.

\section{Kinship's Terms of Address}

In the terms of address, these terms are classified into kinship's terms of address caused by blood and marriage.

\section{The Form of Kinship's Terms of Address Caused by Blood/Descent}

The kinship's terms of address used for interlocutor who have blood relations Abung Lampungese society are adjusted according to gender, generation level, origin of family environment, level of relationship, situation of conversation, origin of term, origin of title, differences in traditional authority levels, differences in birth order, differences of age level, terms of address in religious stuff, and intimate terms of addressing someone, as shown in the following table.

TABLE I

EGO TERMS OF ADDRESS (0) TO FATHER AND MOTHER (GENERATION +I)

\begin{tabular}{|c|c|c|c|c|c|}
\hline \multirow[t]{2}{*}{ No. } & \multirow{2}{*}{$\begin{array}{l}\text { Terms of Address in } \\
\text { Indonesian }\end{array}$} & \multirow[t]{2}{*}{ No. } & \multirow{2}{*}{$\begin{array}{l}\text { Terms of Address in Abung } \\
\text { Lampungese Language }\end{array}$} & \multicolumn{2}{|c|}{ Gender } \\
\hline & & & & Male & Female \\
\hline \multirow[t]{15}{*}{1.} & \multirow{15}{*}{ Bapak (father) } & 1. & Abah & $\sqrt{ }$ & - \\
\hline & & 2. & $A b i$ & $\sqrt{ }$ & - \\
\hline & & 3. & Abuya & $\sqrt{ }$ & - \\
\hline & & 4. & Ayah & $\sqrt{ }$ & - \\
\hline & & 5. & Bapak & $\sqrt{ }$ & - \\
\hline & & 6. & Buya & $\sqrt{ }$ & - \\
\hline & & 7. & Buyah & $\sqrt{ }$ & - \\
\hline & & 8. & Papa & $\sqrt{ }$ & - \\
\hline & & 9. & Papah & $\sqrt{ }$ & - \\
\hline & & 10. & Papi & $\sqrt{ }$ & - \\
\hline & & 11. & Pak & $\sqrt{ }$ & - \\
\hline & & 12. & $P a h$ & $\sqrt{ }$ & - \\
\hline & & 13. & Ubak & $\sqrt{ }$ & - \\
\hline & & 14. & Walid & $\sqrt{ }$ & - \\
\hline & & 15. & $Y a h$ & $\sqrt{ }$ & - \\
\hline \multirow[t]{13}{*}{2.} & \multirow[t]{13}{*}{ Ibu (mother) } & 1. & Bunda & - & $\sqrt{ }$ \\
\hline & & 2. & Ebok & - & $\sqrt{ }$ \\
\hline & & 3. & Emak & - & $\sqrt{ }$ \\
\hline & & 4. & Mak & - & $\sqrt{ }$ \\
\hline & & 5. & Ibeu & - & $\sqrt{ }$ \\
\hline & & 6. & $I b u$ & - & $\sqrt{ }$ \\
\hline & & 7. & $B u k$ & - & $\sqrt{ }$ \\
\hline & & 8. & Ina & - & $\sqrt{ }$ \\
\hline & & 9. & Mama & - & $\sqrt{ }$ \\
\hline & & 10. & Mamah & - & $\sqrt{ }$ \\
\hline & & 1. & Mami & - & $\sqrt{ }$ \\
\hline & & 12. & Ummei & - & $\sqrt{ }$ \\
\hline & & 13. & Ummi & - & $\sqrt{ }$ \\
\hline
\end{tabular}


The terms of address used by the ego (speaker), the generation 0 to the parents (father), male, and generation +1 (above ego) are Abah, Abi, Abuya, Ayah, Bapak, Buya, Buyah, Papa, Papah, Papi, Pak, Pah, Ubak, Walid, and Yah. The terms of address used by the ego (speaker), generation 0 to the parents (mother), female, generation +1 (above ego) are Bunda, Ebok, Emak, Mak, Ibeu, Ibu, Buk, Ina, Mama, Mamah, Mami, Ummei, dan Ummi. The terms of address Pak, Pah, Yah, Mak, dan Buk are the shorten terms from Bapak, Papah, Ayah, Emak, dan Ibu. The terms of address to father and mother are determined by the gender differentiation, everyone is able to use those terms of addresss, in accordance with family's agreement.

The terms of address used by Ego to grandfather, generation +2 (above ego), male, are Ateu, Atu, Atu Ama, Atu Ayah, Atu', Datuk, Sidei, Sidi, Ya 'i, and Yayik. The terms of address used by Ego to grandmother, generation +2 (above ego), female, are Ateu, Atu, Atu Inak, Atu Umik, Ambai, Andung, Inak, Nenek, Nyaik, Sitei, and Siti.

The terms of address used by ego to great grandfather, generation +3 (above ego), male or female, are Buyut, Teludan, Tuyuk. Tuyuk Ragah can be the alternative to address the great grandfather while to address great grandmother, Tuyuk Sebai can also be used. The terms of address used by the ego to the great-great grandfather, generation +4 (above ego), for both male and female are the same; Canggah dan Taring.

The terms of address used by ego to uncle and aunt, generation +1 (equal to father and mother) are determined by gender. To address male, they use Abah, Abuya, Adẻk, Adin Pesirah, Apak Adin, Ayah, Ayah Suttan, Ayah Pengiran, Ayah Rajo, Ayah Rateu, Ayah Atu, Jejuluk, Manda, Minak, Om, Opa, Pak Adin, Pak Atu, Pak Minak, Pak Dalom, Pak Odo, Pak Cik, Pak Su, Pak Tut, Papah, Papi, Puan, Uwak, Wan + Nama, and Walid. The term of address used by ego to aunt, generation +1 (equal to father/mother), are Bunda, Cik Ngah, Halati, Ibeu, Ibu, Ibeu Suttan, Ibeu Tuan, Ibeu Pengiran, Ibeu Rajo, Ibeu Ratu, Ina, Mami, Mak Wan, Mak Ngah, Mak Seu, Mak Su, Mak Tut, Mak Cik, Mak Wo, Minan, Nama diri (proper name), Puan, Puan + Adék, Tante, Tut, Umei, Uncu, Umi, Uwak, Wan + Nama, and Walida.

The terms of address based on birth order of parents' (father/mother) brothers are Pak Adin $\left(6^{\text {th }} / 7^{\text {th }}\right.$ in birth order), Pak Minak, Minak (5 ${ }^{\text {th }}$ in birth order), Pak Dalom (6 ${ }^{\text {th }}$ in birth order), Uwak, Pak Odo (born before father/mother), Pak Ngah (birth order in the middle), Pak Cik (born after father/mother), Pak Seu, Pak Su, dan Pak Tut (the youngest). The terms of address to father/mother's sisters are Wo, Uwak, Puan, Mak Ngah, Cik Ngah, Mak Cik, Mak Seu, Mak Su, Mak Tut, Minan, and Uncu. Uwak is used to address father/mother's sibling whose age are older than them while Om and Tante are used to address father/mother's younger siblings.

Terms of address to siblings are determined by gender, birth order, age status, and marital status. To address brothers, the terms of address used are Abang, Adék, Adin, Ajo, Aying, Bang, Batin, Daying, Jejuluk, Kanjeng, Kiai, Minak, Tihang Ratu, Tuan, Kakak, Tuanda, Uhta, and Nama diri (proper name). While for addressing sister, the terms of address used are Acik, Adék, Atin, Ateu, Atu, Aying, Batin, Daying, Gusti, Jejuluk, Kakak, Kak Atu, Kanjeng, Kiai, Suhun, Susi, Tati, Titah, Tuanda, Uhti, Uni, dan Nama diri (proper name). The terms of address distinguished by the age status are Uni (older than ego) and Nama diri (younger than ego).

Based on marital status, the terms of address used are Jejuluk (single) and Adék (married). The terms of address to siblings used based on birth order are Kanjeng, Gusti, Ateu, Atu, Adin, Ajo, Kiai, Aying/Daying, Atin/Batin, dan Minak. Further explanation of terms of address used based on birth order are on the table below.

TABLE II

TERMS OF ADDRESS TO NIECE AND NEPHEW (EQUAL TO OWN CHILDREN/-1)

\begin{tabular}{|c|c|c|c|c|c|c|c|}
\hline \multirow[t]{2}{*}{ No. } & \multirow{2}{*}{$\begin{array}{l}\text { Terms of address } \\
\text { in Indonesian }\end{array}$} & \multirow[t]{2}{*}{ No. } & \multirow{2}{*}{$\begin{array}{l}\text { Terms of address in } \\
\text { Abung Lampungese } \\
\text { Language }\end{array}$} & \multicolumn{2}{|c|}{ Gender } & \multicolumn{2}{|c|}{ Marital Status } \\
\hline & & & & Male & Female & Single & Married \\
\hline \multirow[t]{5}{*}{3} & \multirow{5}{*}{$\begin{array}{l}\text { Keponakan } \\
\text { (Niece/Nephew) }\end{array}$} & 1. & Adék & $\sqrt{ }$ & $\sqrt{ }$ & - & $\sqrt{ }$ \\
\hline & & 2. & Jejuluk & $\sqrt{ }$ & $\sqrt{ }$ & $\sqrt{ }$ & - \\
\hline & & 3. & Nakan & $\sqrt{ }$ & $\sqrt{ }$ & - & - \\
\hline & & 4. & Naken & $\sqrt{ }$ & $\sqrt{ }$ & - & - \\
\hline & & 5. & Nama diri & $\sqrt{ }$ & $\sqrt{ }$ & - & - \\
\hline
\end{tabular}

To address both niece and nephew, the terms of address used are Adék, Jejuluk, Nakan, Naken, and Nama diri. Adék is used to address married nephew/niece, while Jejuluk is used to address single nephew/niece. Nakan and Naken means niece or nephew. Nama diri is the niece/nephew's own name. as an example, if the nephew's name is Nurdin, he then will be addressed as Nurdin.

The terms of address used by the ego to cousins (children from father/mother's siblings) are Adék, Abang Acik, Adik, Adin, Gusti, jejuluk, Kiay, Kanjeng, Patih, Rateu, Ratu, Ses, Nama diri (proper name). The way they address cousins are similar to when they address siblings and it should be based on birth order. It is determined by gender, age status, marital status.

The terms of address to cousins are determined by male gender are adék, Abang, Adik, Adin, Jejuluk, Kanjeng, Kiay, Patih, Rateu, Ratu, Nama diri (proper name), and similar to addressing siblings. The terms of address to female cousins are Adék, Adik, Acik, Gusti, Jejuluk, Kanjeng, Kiay, Rateu, Ratu, Ses, Nama diri (proper name), and similar to addressing siblings. 
The terms of address to cousins determined by age status are distinguished into younger than ego, older than ego, same age with ego. Those terms of address are Abang (older than ego), Adik (younger than ego), and Nama diri/ proper name (same age with ego).

The terms of address used by ego to his children are Adék, Anak, Bagus, jejuluk, Nak, Nama diri (proper name), Nduk, Sayang, and based on the order of birth. The terms of address to the children are determined by the birth order, marital status, and intimate terms of address. For example, the terms of address Abang, Kanjeng, Kiay are used based on the birt of order.

Jejuluk dan Adék are determined based on the marital status. Bagus is the intimate terms of address for boy and Nduk is the intimate terms of address for girl. Sayang is the intimate terms of address for both boy and girl.

Terms of address used by ego to address grandson or granddaughter are Adék, Jejuluk, Nama diri (proper name), Sayang, dan Uррu. Those terms of address are determined by the marital status and intimate terms of address. Jejuluk is used to address unmarried/single grandson/granddaughter and Adék to address married grandchildren. The term of address used for intimate terms is Sayang.

\section{Kinship's Terms of Address Due to Marriage}

The terms of address used by the ego to her husband are Abang, Adék, Ajo, Ayah, Bang, Kanjeng, Kiay, Papah, similar to the terms of address used in the husband's family, similar to the terms of address used by their children, and Sayang. The terms of address to husband are determined by the traditional authority terms of address. It depends on their fondness as a couple. Some will address their husband similarly to the terms of address used in the husband's family and others will address their husband similarly to the terms of address used by their children. Besides, some will address their husband sayang as the intimate terms of address.

Terms of address used by ego to address wife are Adek, Adék, Adik, Dek, Mamah, Ibu, proper name (nama diri), similar to the terms of address used in the wife's family, similar to the terms of address used by their children and Sayang (dear/honey, etc). The terms of address used for wife are usually determined by traditional authority terms of address.

The terms of address used by ego to address father and mother in-laws are similar to the terms of address used in the husband/wife's family. For example, when the children of father and mother in-law address their parents Abah/Papah/Ayah/Ibeu/Umi, then the ego will address his/her father/mother in-law the same way.

Besan means people whose children are married to each other. The terms of address used by ego to address his/her besan are Sabai, Sada, Adék, and based on the level of courtesy title. Sabai is used to address to male besan, while Sada is used to address female besan. Beside Sabai dan Sada, Adék and gelar jenjang adat also can be used to address both male and female besan. As the example, Adék besan whose title is Ratu Syah Alam, then the ego will address his besan, Ratu syah Alam.

The proper terms of address based on birth order is used to address both brother-in-law and sister-in-law. Kanjeng, Gusti, Rateu (the first in birth order), Kiay (the second in birth order), Daying (the third in birth order) etc are the terms of address used based on birth order. The terms of address used to address brother-in-law and sister-in-law should be based on the traditional authority level; Suttan $\left(1^{\text {st }}\right.$ level $)$, Tuan $\left(2^{\text {nd }}\right.$ level $)$, Pengiran $\left(3^{\text {rd }}\right.$ level $)$, etc.

In determining the terms of address, the status of both speakers should be appropriate. For example, the younger one will address the older addressee with Kiay atau Kanjeng. The older one will address the younger addreseee with Adik or proper name.

The terms of address used to address son-in-law or daughter-in-law are Adék, Matew, proper name, based on the level of courtesy title and based on the name of first son-in-law (the name of first grandchild from father/mother-in-law). The term of address Adék is owned bya the son-in-law after he get the courtesy title since he is already married. For example, his previous proper name is Zainudin, after he get married, he becomes Pengiran Sakti, then he will be addressed Pengiran Sakti. Sapaan Matew berarti Menantu. This term of address can be used for son-in-law and daughter-in-law.

Non-Kinship Term of Address

Non-kinship terms of address are classified into non-kinship same ethnic and non-kinship same ethnic. The terms of address in these two groups are also classified into stranger interlocutor and familiar interlocutor.

\section{Terms of Address to the Same Ethnic Interlocutor}

The terms of address to the same ethnic interlocutor are divided into a stranger interlocutor and familiar interlocutor from the same ethnic.

(1) Stranger Interlocutor from the same ethnic

In general, the terms of address used to the stranger interlocutor with same etnic depend on the gender and the age of interlocutor. The common terms of address used are Buya, (bapak), Ibeu (ibu), Datuk/Atu' (kakek), Nyaik/Atu (nenek), Kiay (the interlocutors are the same age or little bit older than the speaker), Adik/Adek (the interlocutors are younger than the speaker), and Nak/Anak (child).

(2) Familiar Interlocutor from the same ethnic

To address familiar interlocutor from the same ethnic, the speaker will use the same terms off address as used in addressing relatives. (See the previous terms of address)

The Non-Kinship Terms of Address to Interlocutor from Different Ethnic 
Non-kinship terms of address are classified into non-kinship different ethnic and non-kinship different ethnic. The terms of address in these two groups are also classified into stranger interlocutor and familiar interlocutor.

(1) Stranger interlocutor from different ethnic

The speaker will consider the gender and the age of the stranger interlocutor from different ethnic by using common terms of address such as Bapak, Pak, Ibu, Bu, Kakek, Kek, Nenek, Nek, Kakak, Kak, Adik, Dik, Abang, Bang, Mbak, Mas, dll.

(2) Familiar interlocutor from different ethnic

To address familiar interlocutor from different ethnic, the speaker will use common terms of address or without the mentioning the profession such as Pak Guru, Bu Guru, Mas, Mbak, Mbah, Nenek, Mang, Uda, Encik, Uni, Babah, Pak Ustad, dll.

\section{Intimate Terms of Address}

This termsae used to express deep love and care to the interlocutor. The Abung Lampungese society use Bagus, Nduk, and Sayang. Bagus is used by the parents to son and by the grandparents to grandson or great-grandson. $N d u k$ is used by the parents to daughter and by the grandparents to granddaughter or great-granddaughter. Sayang is used by the parents and grandparents to son and daughter, grandchildren, and great-grandchildren. Sayang is also used by the husband to wife or vice versa.

The Form of Term of Reference

The Form of Term of Reference is used to address blood-related relative interlocutors.

Terms of Reference based on Types Pronoun

TABLE III

TERMS OF REFERENCE BASED ON TYPES PRONOUN

\begin{tabular}{|c|c|c|c|c|c|c|c|c|c|}
\hline \multirow[t]{3}{*}{ No. } & \multirow{3}{*}{$\begin{array}{l}\text { Terms of Reference in } \\
\text { Indonesian }\end{array}$} & \multirow[t]{3}{*}{ No. } & \multirow{3}{*}{$\begin{array}{l}\text { Terms of } \\
\text { Reference in } \\
\text { Abung } \\
\text { Lampungese } \\
\text { Language }\end{array}$} & \multicolumn{6}{|c|}{ Types of Pronoun } \\
\hline & & & & \multicolumn{3}{|c|}{ Singular } & \multicolumn{3}{|l|}{ Plural } \\
\hline & & & & $1^{\mathrm{st}}$ & Or $2^{\text {nd }}$ & Or $3^{\text {rd }}$ & Or $1^{\text {st }}$ & Or $2^{\text {nd }}$ & $\mathrm{O}^{\text {rd }}$ \\
\hline \multirow[t]{3}{*}{1.} & \multirow[t]{3}{*}{ Saya/Aku (I) } & 1. & Nyak & $\sqrt{ }$ & - & - & - & - & - \\
\hline & & 2. & Ekam & $\sqrt{ }$ & - & - & - & - & - \\
\hline & & 3. & Hikam & $\sqrt{ }$ & - & - & - & - & - \\
\hline 2. & Kamu (You) & 2. & Nikew & - & $\sqrt{ }$ & - & - & - & - \\
\hline 3. & Anda (You) & 1. & Metei & - & $\sqrt{ }$ & - & - & - & - \\
\hline \multirow[t]{4}{*}{4.} & \multirow[t]{4}{*}{ Dia (She/He) } & 1. & $Y o$ & - & - & $\sqrt{ }$ & - & - & - \\
\hline & & 2. & Diya & - & - & $\sqrt{ }$ & - & - & - \\
\hline & & 3. & Yow & - & - & $\sqrt{ }$ & - & - & - \\
\hline & & 4. & Yew & - & - & $\sqrt{ }$ & - & - & - \\
\hline 6. & & 2. & Kuti Ghumpok & - & - & - & - & $\sqrt{ }$ & - \\
\hline 7. & Mereka (They) & 1. & Tiyan & - & - & - & - & - & $\sqrt{ }$ \\
\hline 8. & Beliau (He/She) (polite) & 1. & Beliaw & - & - & $\sqrt{ }$ & - & - & - \\
\hline
\end{tabular}

The term of address determined by pronouns are Nyak, ekam, Hikam, Nikeu, Nikew, Metei, Yo, Diya, Yow, Yew, Ekam, Hikam, Sikam, Kuti, Kuti Ghumpok, Tiyan, and Beliaw. Nyak/Ekam/Hikam (I) is used for first person-singular pronoun. Nikeu/Nikew (you) is used for second person-singular pronoun. Metei (You) is used for second person-singular pronoun. Yo/Diya/Ypw/yew (she/he) is used for third person-singular pronoun. Ekam/Hikam/Sikam (we) is used for first person-plural pronoun. Kuti dan Kuti Ghumpok (You) are used for second person-plural pronoun. Tiyan (They) is used for third person-plural pronoun. Beliaw (He/she) is used for third person-singular pronoun.

\section{The Terms of Address in Courtesy Title}

The terms of address in courtesy title of Abung Lampungese language are distinguished into courtesy title of terms of address based on traditional authority institution, terms of address based on marital status and terms of address based on birth order.

(1) Courtesy title of terms of address based on traditional authority institution

Abung Lampungese speaker society has traditional authority institution called Kepenyimbangan. The officers in Kepenyimbangan are classified based on level/stratification, role, and responsibilities in the institution. Each group has different terms of address. The table below explains the stratification of terms of address. 
TABLE IV

TRADITIONAL AUTHORITY TERMS OF ADDRESS STRATIFICATION

\begin{tabular}{|l|l|l|l|l|l|l|}
\hline No. & Traditional Authority Terms of Address Stratification & \multicolumn{2}{|l|}{ Stratification } & \multicolumn{1}{l|}{} \\
\cline { 3 - 7 } & & 1 & 2 & 3 & 4 & 5 \\
\hline 1. & Suttan & $\sqrt{ }$ & - & - & - & - \\
\hline 2. & Tuan & - & $\sqrt{ }$ & - & - & - \\
\hline 3. & Pengiran & - & - & $\sqrt{ }$ & - & - \\
\hline 4. & Rajo & - & - & - & $\sqrt{ }$ & - \\
\hline 5. & Rateu/Batin/Dalem/Minak/Radin & - & - & - & - & $\sqrt{ }$ \\
\hline
\end{tabular}

Abung Lampungese society follows a traditional authority called Pepadun. There is social stratification which will determine the responsibilities, functions, and roles of given courtesy title adék in Abung Lampungese society. This courtesy title is given to married person who is able to hold special ceremonial called gawei mepadun (the highest ceremonial in Lampungese traditional Authority). This adék courtesy title determines the term address used. This courtesy title applies to both male and female. The terms of address stratification in courtesy title are Suttan (jenjang 1), Tuan (jenjang 2), Pengiran (jenjang 3), Rajo (jenjang 4), Rateu/Batin/Dalem/Minak/Radin (jenjang 5),

\section{Terms of Address based on Marital Status}

Based on marital status, terms of address are divided into Jejuluk and Adék. Jejuluk is the traditional authority terms of address to address newly born child. Jejuluk is given at the thanksgiving ceremonial and akikahan once at the same time by cutting the baby's hair called Marhabanan. In akikahan, the parent will slaughter two lambs for baby boy and a lamb for baby girl. Only the grandparents and the uncles/aunts who have the rights to give courtesy title Jejuluk to the baby. The baby will bear the title until he or she gets married. The example of Jejuluk:

Name: Regina Zarifa; Courtesy title Jejuluk: Pengiran Juwita

Adék is the traditional authority term of address based on marital status. This term of address is used to someone who has aleady married. The title of Adék is announced on the wedding ceremony and given by Penyimbang Adat (traditional authority leader). To give this courtesy title, the parents' ancestry (father) should be considered. Contoh:

Proper name: Ahmad Effendy Sanusi; title Adék: Suttan Siwo Mego

\section{Terms of Address of Proper Name}

Similar to other ethnics, Abung Lampungese people has a traditional authority to give name as an identity. The proper names used in Abung ethnic can also be found in other Lampungese society. Those names are taken from Arabic language, common name or western name. Example: Wan Abas, Muhammad Idris, Komarudin, Evi Saputra, Hesti, Sherly.

\section{Term of Names in Religious/Spiritual Matter}

The religious terms of address are commonly used in Abung Lampungese language speakers. Religious terms of address are used to address the spoken opponents who work in spiritual area or those who have been to Mecca as pilgrims. Religious terms of address are Pak Aji, Mak Aji, Nyaik Aji, Pak Ustad, Mrs. Ustadzah, Pak Imam, and Pak Penghulu.

\section{B. The Rules for the Use of Terms of Address of Lampungese Language Speaker}

The use of terms of address in Lampungese language is based on its rules. Those rules includes gender, origin of the family environment, origin of heredity, birth order, courtesy title, age status, religious title, situation of conversation, and purpose of using terms of address factors. The following is a description of each of the rules.

a) The gender factor of the speech actor will determine the use of the terms of address. The terms of address to address male may be different with female. For example, the only term used to address the eldest brother is Kanjeng, while the terms of address used to address the eldest sister are Kanjeng, Gusti, or Ratu.

b) The origin of the family environment must be considered by the speech participants. The noble family environment will use different term sof address compared to ordinary or non noble family; asal lingkungan keluarga Penyimbang family will use different terms of address compared to non Penyimbang (the traditional authority leader) family, the origin of the family who has been to Mecca as pilgrims will be different compared to the family who has not been to Mecca as pilgrims, etc.

c) In determining the terms of address in Lampungese traditional authority, the origin of descent should be carefully noticed. The speakers from noble class Penyimbang Adat will use different terms of address to ordinary descent people. The origin of parents will also determine the usage of terms of address. For example, the siblings from father's line will be called Lebew/Lebu, while the siblings from mother's line will be called Batangan.

d) The birth order will determine the terms of address used, role, right, obligation and responsibilities to the one who use that term of address. The terms of address used for the first child will be different to the terms of address used for the second child, etc. The eldest boy will be addressed Kanjeng. Kanjeng will play a role as the replacement/representative of father in deciding things or making decision in the family when the father is absent. Besides, he has the right to stay in his parents' house forever and get all of the inheritance of the parents. Kanjeng must protect and help his younger siblings both in household and his siblings' needs. Kanjeng are responsible of his siblings' welfare, harmony and survival. 
e) In using the terms of address, the courtesy title determines the status, role, right, and responsibilities possed by the person concerned. The courtesy title from marital status (married or not) will have different rules in its use. The courtesy title for unmarried/single person is called Juluk/Jejuluk, while the title for married person is called Adék/Adok. There is another courtesy titles of traditional authority institution which has different stages, these stages will determine the terms of address.

f) Age will determine the terms of address. Older people will have different terms of address from younger or of the same age people.

g) Religious title must be considered since it is used to respect, it also distinguishes one's status in the conversation and it gives roles to the speech actor. Those who has been to Mecca as pilgrims are highly respected, they are called jaji to show the respect. Those who work in religious sector (Qur'an teacher, imam in mosque, and chief) will be addressed with certain terms of address to distinguish them from others. It also shows the respect.

h) In using the terms of address, the situation of the conversation should be considered. In formal situation, especially in traditional ceremony, the use of terms of address in courtesy title, both Adék/adok from marital status and Adék/adok from institution of traditional authority, must be prioritized. While in informal situation, the term of address is adjusted to the habits occurred in the family or the society concerned.

i) The function or the purpose of the using of terms of address must be taken into account. The term of address used to respect someone is different from the term of address used to express love, etc.

\section{CONCLUSION}

The terms of address of Lampungese Language includes 1) the terms of address in kinship, based on the relationship and descent of the marriage bond; 2) non-kinship terms of address, interlocutor from same ethnic, stranger from same ethnic, new people from same ethnics, colleagues from same ethnic, other ethnicities, new people from other ethnic groups, colleagues from other ethnicities; 3) terms of address from family's environment; religious family, ordinary family, noble family; 4) intimate terms of address; 5) terms of address of saying something; 6) terms of address in birth order; 7) term of address in courtesy title, includes level or the stage in traditional authority, term of address in marital status (Jejuluk/Juluk, Adék/Adok); 8) religious/ spiritual terms of address; 9) terms of address in pronouns; and 10) terms of address in proper name.

The factors of the terms of adress rules and norms in Lampungese are 1) relative or non relative, 2) generation, 3) sex and gender, 4) age, 5) birth order, 6) the origin of family's environment, 7) marital status, 8) the level or the stage of traditional authority, 9) religious or spiritual, 10) ethnic, 11) situation of conversation, 12) the purpose of the conversation.

\section{REFERENCES}

[1] Hadikusumah, Hilman. (1988). Bahasa lampung. Jakarta: Fajar Agung.

[2] Hadikusuma Hilman, Razi Arifin, RM. Barusman. (1996). Adat istiadat daerah lampung. Bandar Lampung: CV. Arian Jaya.

[3] Koentjaraningrat. (1990). Pengantar ilmu antropologi. Jakarta: PT Rineka Cipta.

[4] Kramsch, Claire. (1998). Language and culture. New York: Oxford University Press

[5] Lyons, John. (1995). Linguistic semantics: An introduction. Cambridge: Cambridge University Press.

[6] Poedjosoedarmo, Soepomo. (1968). Javanese speech level. Ithaca: Cornell University Press.

[7] Poedjosoedarmo, Soepomo. (2009). Sosiolinguistik. Yogyakarta: Pustaka Pelajar.

[8] Sibarani, R. (2004). Antropolinguistik: Antropologi linguistik. Medan: Penerbit Poda.

[9] Trudgill, P. (1995). Sociolinguistics: An introduction to language and society. Harmondsworth, England: Penguin Books.

[10] Wardaugh, Ronald. (1986). An introduction to sociolinguistics. Oxford: Blackwell.

[11] Wijana, I Dewa Putu, \& Muhammad Rohmadi. (2006). Sosiolinguistik kajian teori dan analisis. Yogyakarta: Pustaka Pelajar.

[12] Wijana, I Dewa Putu. (2010). Pengantar semantik bahasa indonesia. Yogyakarta: Universitas Gadjah Mada and Pustaka Pelajar.

Iing Sunarti, M.Pd. was born in Sukabumi, West Java, Indonesia, on November $16^{\text {th }} 1958$. She earned her undergraduate degree in Indonesian language and literature education of faculty of teacher training and education, University of Lampung. She then continued her master in same program in Indonesian Education University and her post graduate degree in Gajah Mada University in 2016

Iing has became a lecturer in Indonesian language and literature education, Faculty of Education and Teacher Training, University of Lampung for undergraduate students since 1987, she then starts teaching master program of Indonesian language and literature education and master program in Lampungese Language and Literature Education. She teaches linguistics, sociolinguistics, psycholinguistics, semantics, language research methods and speaking class. She interested in Indonesian language and literature education.

Iing Sunarti joins Indonesian Linguistics Society (Masyarakat Linguistik Indonesia/MLI), Organisasi professional yang diikutinya ialah Masyarakat Linguistik Indonesia (MLI), Indonesian Regional Culture Lecturer Association (Ikatan Dosen Budaya Daerah Indonesia/ IKADBUDI), and Association of Indonesian Cultural Scholars (Himpunan Sarjana Kebudayaan Indonesia/ HISKI). She has published some articles such as (1) Tutur/Tutor Bahasa Lampung (International Conference Proceeding IKADBUDI, 2016), (2) Etika Budaya Bertutur Sapa Masyarakat Etnis Lampung (National Seminar Proceeding, 2017), (3) Faktor-Faktor yang Menentukan 
Pemilihan Bentuk Sapaan Bahasa Lampung Pubian (International Seminar Proceeding, 2018), (4) Bahasa Cirebon di Pulau Pasaran Bandar Lampung (International Seminar, 2018), and (5) (6) The Fulfilment Of Student's Deficiency Need By Teacher' S Directive Speech Act Strategy Which Get Positive Affective Color Response (Thomson Reuters, 2018).

Sumarti, M. Hum. was born in Cirebon. West Java, Indonesia, on March $18^{\text {th }}$, 1970. She completed her undergraduate degree at the Indonesian Language and Literature Study Program IKIP Bandung in 1992. In 1998, she earned her master program in the Literature Study Program with Linguistics concentration in Padjadjaran University Bandung. She continued her post doctoral degree the Program Indonesian Language Education in Indonesia Indonesia Education University Bandung. Her field of specialization is Indonesian Language Education.

Since 1994, Sumarti has become a lecturer in Indonesian language and literature education, Faculty of Education and Teacher Training, University of Lampung for undergraduate students. In 2015, she started teaching in master program of Indonesian lan guage and literature education and master program in Lampungese Language and Literature Education. She teaches linguistics, phonology, syntax, Indonesian structure, semantics, journal review, Problematic Learning of Indonesian Language and Literature and Learning Indonesian Speaking Skills for speakers from other language. Her focus and interest of research is linguistics and its application in Indonesian language learning

She joins Indonesian Language and Literature Lecturer Association (Asosiasi Dosen Bahasa dan Sastra Indonesia/ADOBSI), Indonesian Linguistics Society (Masyarakat Linguistik Indonesia/MLI), Indonesian Regional Culture Lecturer Association (Ikatan Dosen Budaya Daerah Indonesia/ IKADBUDI), and Association of Indonesian Cultural Scholars (Himpunan Sarjana Kebudayaan Indonesia/ HISKI). She has published several publications; (1) Strategi Tindak Tutur Direktif Guru dan Respons Warna Afektif Siswa (UPI Educational Research Journal, 2015), (2) Prinsip Tenggang Rasa Masyarakat Etnis Cirebon di Pulau Pasaran Bandar Lampung (IKADBUDI International Conference Proceeding, 2016), (3) Pembelajaran Berbicara Berbasis Tipologi Bahasa dan Kearifan Lokas bagi Penutur Asing di Universitas Lampung (International Conference Proceeding of Teaching Indonesian to speakers of other languages KIPBIPA X, 2017), (4) Bahasa Cirebon di Pulau Pasaran Bandar Lampung (International Conference Proceeding, 2017), (5) Faktor-Faktor yang Menentukan Pemilihan Bentuk Sapaan Bahasa Lampung Pubian (International Conference Proceeding, 2018), dan (6) The Fulfilment Of Student's Deficiency Need By Teacher' S Directive Speech Act Strategy Which Get Positive Affective Color Response (Thomson Reuters, 2018).

Bambang Riadi, S.Pd., M.Pd. was born in West Lampung on June $30^{\text {th }}$, 1984. He earned his undergraduate degree at the Indonesian Language and Literature Study Program, Faculty of Teacher Training and Education, University of Lampung. He completed his master degree at the Indonesian Language and Literature Study Program at the same university in 2013.

Since 2014, Bambang has become a lecturer in Indonesian language and literature education, Faculty of Education and Teacher Training, University of Lampung for undergraduate students. he teaches reading, problematic learning of Indonesian Language and Literature, syntax, and morphology. His focus and interest of research is Indonesian Language Education.

He joins Indonesian Linguistics Society (Masyarakat Linguistik Indonesia/MLI), Indonesian Regional Culture Lecturer Association (Ikatan Dosen Budaya Daerah Indonesia/ IKADBUDI), and Association of Indonesian Cultural Scholars (Himpunan Sarjana Kebudayaan Indonesia/ HISKI). He has published several publications; (1) Kemampuan membaca kritis dengan teknik SQ3R Mahasiswa Prodi Pend. Bahasa dan Sastra Indonesia (Aksara Journal, 2015), (2) Variasi Kode dalam Tuturan Mayarakat Jawa di Gedongtataan (Aksara Journal, 2017), dan (3) Faktor-Faktor yang Menentukan Pemilihan Bentuk Sapaan Bahasa Lampung Pubian (International Seminar Proceedings, 2018). 